\title{
Atrial fibrillation: the rate versus rhythm management controversy
}

\author{
${ }^{1} \mathrm{AJ}$ Camm, ${ }^{2}$ I Savelieva \\ ${ }^{1}$ Professor of Clinical Cardiology; ${ }^{2}$ Senior Research Fellow; St. George's Hospital Medical School University of London, London, UK
}

\begin{abstract}
The fundamental management strategy for atrial fibrillation (AF) is still debated. There is no doubt that those patients at risk of thromboembolic events should be offered anticoagulant therapy. However, it is uncertain whether rhythm control (restoration and maintenance of sinus rhythm) or rate control (adjustment to a physiological ventricular rate while allowing $\mathrm{AF}$ to continue) is the preferred primary treatment option for the reduction of symptoms and major cardiovascular (CV) outcomes associated with AF.
\end{abstract}

Several well conducted trials comparing the two strategies led to the conclusion that there was little to choose between them. However, guidelines leaned towards recommending rate control as the initial strategy, and reserved rhythm control for those who remained symptomatic. Recently this status quo is being increasingly challenged by the clear demonstration that left atrial catheter ablation is effective at suppressing AF resistant to traditional antiarrhythmic drugs, such as those that failed to demonstrate any superiority when compared with rate control. Also, recently introduced antiarrhythmic therapy may have superior efficacy with regard to reducing unexpected $\mathrm{CV}$ hospitalization, $\mathrm{CV}$ mortality and stroke. In addition, there is a growing perception that atrial remodelling should be best prevented by early rhythm control rather than delaying until rate control has proven unsatisfactory.

For these reasons the results of large randomised clinical trials, which recruit patients soon after the presentation of AF and compare 'aggressive' modern rhythm control against the guideline approach of primary rate control, are eagerly awaited. In the meantime the pendulum of clinical opinion has begun to swing towards a rhythm control strategy.

DECLARATION OF INTERESTS Professor Camm has consulted and spoken on behalf of Sanofi, Merck, Menarini, Medtronic and Boston Scientific. Dr Savelieva has spoken on behalf of Sanofi.

\section{INTRODUCTION}

Atrial fibrillation (AF) is an increasingly prevalent arrhythmia, affecting close to $2 \%$ of the general population. ${ }^{1.2}$ It accounts directly for over $15 \%$ of all strokes; many cryptogenic strokes may also be due to this arrhythmia. ${ }^{3.4}$ Hospitalizations for the management of $A F$ itself, acute coronary syndrome and for heart failure are increased when $A F$ is present. ${ }^{5-7}$ Exercise tolerance is generally reduced and quality of life is impaired, especially in symptomatic patients. ${ }^{89}$

AF occurs in conjunction with almost every cardiac or vascular disease and may also complicate diseases of the chest. ${ }^{10}$ It may result from aging alone; most of the patients with this arrhythmia are relatively old and have underlying cardiac or pulmonary pathology. In younger patients, structural congenital cardiac disease or an association with channelopathies (QT abnormalities and Brugada syndrome), or familial cardiomyopathy (e.g. hypertrophic cardiomyopathy) may be responsible." The
Correspondence to AJ Camm, Division of Clinical Sciences, St. George's University of London, Cranmer Terrace,

London, SWI 7 ORE,

United Kingdom

jcamm@sgul.ac.uk majority of younger patients however have no apparent cardiovascular cause for their AF, other than mild hypertension (without left ventricular hypertrophy) or possible cardiac autonomic dysfunction. Other elements may also be responsible for the arrhythmia, including genetic factors," a history of an inflammatory illness preceding the first episode, or toxic causes (e.g. alcohol, thyroid conditions, etc.).

While elderly patients, especially when sedentary and inactive, may be relatively asymptomatic from AF, younger patients (who are usually more active) find AF to be a very symptomatic and debilitating disease. ${ }^{2}$ Older patients may blame their symptoms on 'getting old' and accommodate by lowering their expectations and adjusting their lifestyle to the limitations imposed by the disease. Younger patients tend to expect a full eradication of the disease or at least complete suppression of their symptoms. 
AJ Camm, I Savelieva

AF is typically divided into three types (paroxysmal, persistent and permanent) based on its presentation, duration, and response to therapy (if applicable). ${ }^{13}$ Paroxysmal AF is a self-terminating arrhythmia; although the duration of paroxysms may vary greatly (with the upper limit arbitrarily set at seven days) the majority will end within 48 hours. The 48-hour time period is clinically important because after this the likelihood of spontaneous conversion is low and anticoagulation must be considered prior to any attempt to cardiovert the arrhythmia, irrespective of the underlying thromboembolic risk profile. If AF lasts longer than seven days or requires pharmacological or electrical cardioversion, it is referred as persistent. When AF does not convert spontaneously and is refractory to cardioversion or other rhythm control interventions, or if the physician or the patient chooses not to pursue the rhythm control strategy and allow AF to remain, the term permanent ('accepted') AF is applied. AF lasting more than one year (or six months according to recent statements from regulatory authorities (MULTAQ) is deemed to be 'permanent' but if a rhythm control strategy is to be pursued with cardioversion or catheter ablation the AF may be designated as 'long-standing persistent'.

When AF is first detected, it may be a single nonrecurrent event secondary to a reversible or transient cause, or it may evolve into recurrent paroxysmal or persistent AF. The onset of AF however may be asymptomatic and the first detected episode should not be regarded as necessarily the true onset of the arrhythmia. AF episodes may or may not terminate spontaneously. There is usually a progression of the disease from paroxysmal to persistent and eventually permanent (or accepted) AF. ${ }^{14}$ Progression from first diagnosed or recurrent paroxysmal AF to persistent or permanent AF occurs on average at the rate of $5 \%$ to $15 \%$ per year, depending on a number of factors, such as age at presentation and the presence of underlying heart disease (Table I). ${ }^{15}$

\section{RATE VERSUS RHYTHM CONTROL STRATEGIES}

AF is due to very rapid atrial excitations, caused and sustained by a combination of re-entry and automaticity mechanisms, ${ }^{16}$ which effectively paralyze atrial mechanical function. These excitations are conducted (to a limited extent) to the ventricles and induce a rapid and irregular ventricular rate response. There are two fundamentally different clinical approaches to the arrhythmia: ${ }^{13}$

Rate control: Slowing the ventricular rate to a level which is physiologically appropriate. It is not clear exactly what this rate should be, but most clinicians settle for rates at rest below 100 beats per minute. In clinical trials specific definitions have been applied.
Rhythm control: Suppressing the rapid excitation of the atrium and restoring sinus rhythm. Antiarrhythmic drugs (ion channel blockers) are most commonly used for this purpose, but occasionally autonomic manipulation, with beta blockers for example, may also prove effective. Successful rhythm control may eliminate or reduce recurrent $A F$ or slow its progression.

Patients who are not severely symptomatic could be considered for treatment using either strategy. Both patients and physicians have taken part in clinical trials in which these patients were randomised to receive either rate control or rhythm control treatment. Patients who have severe and disabling symptoms often demand a more aggressive approach towards restoring and maintaining sinus rhythm; rate versus rhythm control trials would therefore be difficult, and have never been undertaken.

Rhythm control appears to be a more attractive treatment option, as it offers physiologic rate control, normal atrial activation and contraction, the correct sequence of atrioventricular ( $\mathrm{AV}$ ) activation and normal haemodynamic and $A V$ valve function. It also theoretically eliminates one (stasis) or more (endothelial abnormality or increased thrombogenic blood constituents) of Virchow's triad of elements that encourage thrombosis within the atria and embolization of blood clots to potentially critical parts of the circulation. Advantages of the rate control approach on the other hand include avoiding the potential toxicity of antiarrhythmic drugs or the risks and discomfort associated with electrical cardioversion or invasive left atrial ablation for recurrences of $\mathrm{AF}$.

Sinus rhythm with normal AV conduction may however not be an alternative treatment for AF since sinus node disease may be the underlying problem and chronotropic incompetence may be present. Atrial conduction and mechanical function may be seriously impaired due to existing $A F$, or underlying pathophysiologies such as left ventricular (LV) cavity dilatation, LV hypertrophy, hypertension, mitral valve disease, etc. Atrial contraction may not contribute much to cardiac output. AV conduction may be impaired because of associated structural disease, channelopathy or antiarrhythmic drug therapy. AV valve function may be structurally abnormal or functionally disturbed on a permanent basis because of dilatation of the atrium and $\mathrm{AV}$ valve annulus. AF which is not fully suppressed is likely to cause some symptoms which, when contrasted to asymptomatic periods of sinus rhythm, may make intermittent $A F$ more troublesome than sustained AF.

It is not unusual for patients to be relieved of their symptoms when AF is established and becomes permanent. Often the only symptoms that remain are a minor limitation to exercise tolerance and a subtle 
TABLE I Rates of progression of paroxysmal atrial fibrillation to persistent or permanent atrial fibrillation.

\begin{tabular}{|c|c|c|c|c|c|c|}
\hline Study & $\begin{array}{l}\text { Number } \\
\text { of } \\
\text { patients }\end{array}$ & Age, years & Type of AF & $\begin{array}{l}\text { Follow- } \\
\text { up, years }\end{array}$ & $\begin{array}{l}\text { Progression of } \\
\text { AF, \% }\end{array}$ & $\begin{array}{l}\text { Predictors of } \\
\text { progression (risk) }\end{array}$ \\
\hline $\begin{array}{l}\text { European } \\
\text { Heart Survey, } \\
2010\end{array}$ & 1219 & $64 \pm 13$ & $\begin{array}{l}\text { Paroxysmal; } \\
\text { lone AF: I7\% }\end{array}$ & 1 & \begin{tabular}{|l|}
15 \\
Permanent: 8 \\
In subgroup \\
with lone AF: 7 \\
(persistent or \\
permanent) \\
\end{tabular} & $\begin{array}{l}\text { Age }>75 \text { years }(\mathrm{I} .57) \text {, } \\
\text { heart failure }(2.22) \text {, } \\
\text { hypertension }(\mathrm{I} .52) \text {, } \\
\text { stroke/TIA }(2.02) \text {, } \\
\text { COPD }(\mathrm{I} .5 \mathrm{I})\end{array}$ \\
\hline $\begin{array}{l}\text { RECORD-AF, } \\
2011\end{array}$ & 2137 & $65.1 \pm 12$ & $\begin{array}{l}\text { Recent onset } \\
\text { paroxysmal }\end{array}$ & 1 & $\begin{array}{l}\text { I5 } \\
\text { Permanent: } 9\end{array}$ & $\begin{array}{l}\text { Heart failure (2.2), } \\
\text { hypertension (I.5), } \\
\text { rate control (3.2) } \\
\text { In subgroup with rhythm } \\
\text { control as the initial } \\
\text { strategy: heart failure } \\
\text { (I.9), hypertension (I.8), } \\
\text { heart rate (I.0I) }\end{array}$ \\
\hline $\begin{array}{l}\text { Sakamoto } \\
\text { (Tokyo), } 1995\end{array}$ & 137 & $\begin{array}{l}\text { No } \\
\text { progression: } \\
62.4 \pm 11 \\
\text { With } \\
\text { progression: } \\
70.1 \pm 8.2\end{array}$ & $\begin{array}{l}\text { First detected } \\
\text { paroxysmal }\end{array}$ & 1 & $\begin{array}{l}\text { Sustained AF } \geq 6 \\
\text { months: } 22\end{array}$ & $\begin{array}{l}\text { Age } \geq 65 \text { years, heart } \\
\text { failure, } C T R \geq 50 \%, \\
\text { diabetes, } L A \geq 38 \mathrm{~mm}, \\
\text { LVEF } \leq 0.76, \text { f waves in } V_{\text {, }} \\
\geq 2 \mathrm{~mm}\end{array}$ \\
\hline $\begin{array}{l}\text { Abe (Osaka), } \\
1997\end{array}$ & 122 & $61 \pm 12$ & $\begin{array}{l}\text { Paroxysmal; } \\
\text { lone AF: } 21 \%\end{array}$ & 2.16 & $\begin{array}{l}\text { Sustained AF } \geq 6 \\
\text { months: } 11.5\end{array}$ & $\begin{array}{l}\text { LA size, abnormal } \\
\text { P-signal'-averaged ECG }\end{array}$ \\
\hline $\begin{array}{l}\text { Fauchier } \\
\text { (Tours), } 2010\end{array}$ & 2167 & $71 \pm 14$ & Paroxysmal & 2.6 & 14.1 & $\begin{array}{l}\text { Age }>75 \text { years, heart } \\
\text { failure, hypertension, } \\
\text { COPD, number of } \\
\text { electrical cardioversions, } \\
\text { dilated cardiomyopathy, } \\
\text { prosthetic valve }\end{array}$ \\
\hline $\begin{array}{l}\text { UK GPRD, } \\
2005\end{array}$ & 418 & $\begin{array}{l}\text { Men: } 67 \pm 11 \\
\text { Women: } \\
73 \pm 10\end{array}$ & $\begin{array}{l}\text { First detected } \\
\text { paroxysmal; } \\
\text { no co- } \\
\text { morbidity: } 32 \% \\
\end{array}$ & 2.7 & $\begin{array}{l}\text { II at I year } \\
17 \text { at } 2.7 \text { years }\end{array}$ & $\begin{array}{l}\text { Valvular heart disease } \\
\text { (2.7), moderate to high } \\
\text { alcohol intake (3.0) }\end{array}$ \\
\hline $\begin{array}{l}\text { Al-Khatib } \\
\text { (Durham), } \\
2010\end{array}$ & 231 & $60 \pm 13$ & $\begin{array}{l}\text { Paroxysmal; } \\
\text { lone AF: 4I.6\% }\end{array}$ & 4 & $\begin{array}{l}8 \text { at I year } \\
18 \text { at } 4 \text { years }\end{array}$ & $\begin{array}{l}\text { Age (I.82 per decade), } \\
\text { AF at presentation (3.56) }\end{array}$ \\
\hline $\begin{array}{l}\text { Pappone } \\
\text { (Milan), } 2008\end{array}$ & 106 & $57.5 \pm 11.5$ & $\begin{array}{l}\text { First detected } \\
\text { paroxysmal; } \\
\text { lone AF: } 51 \%\end{array}$ & 5 & $\begin{array}{l}\text { Recurrent } \\
\text { paroxysmal: } 52.8 \\
\text { Persistent: } 53.3^{\mathrm{a}} \\
\text { Permanent: } 35.5^{\mathrm{a}} \\
\text { In subgroup with } \\
\text { lone AF: } \\
\text { 3.7 (persistent), } \\
\text { 1.8 (permanent) } \\
\end{array}$ & $\begin{array}{l}\text { Age (I.19), heart failure } \\
\text { (II.2), diabetes (I7.3), } \\
\text { drug therapy vs ablation }\end{array}$ \\
\hline $\begin{array}{l}\text { Rostagno } \\
\text { (Florence), } \\
1995\end{array}$ & 106 & $63 \pm 11$ & $\begin{array}{l}\text { First detected } \\
\text { paroxysmal } \\
\text { lone AF }\end{array}$ & 6 & \begin{tabular}{|l} 
Recurrent \\
paroxysmal: 55.6 \\
Sustained: $4.7 \%$
\end{tabular} & - \\
\hline $\begin{array}{l}\text { Takahashi } \\
\text { (Tokyo), } 1980\end{array}$ & 94 & 60 & $\begin{array}{l}\text { First detected } \\
\text { paroxysmal; } \\
\text { lone AF: } 24.5 \%\end{array}$ & $>6$ & $\begin{array}{l}\text { Sustained AF } \geq 6 \\
\text { months: } 20.2-25.3\end{array}$ & $\begin{array}{l}\text { Rheumatic valvular } \\
\text { disease; frequency of } \\
\text { paroxysms }\end{array}$ \\
\hline
\end{tabular}


AJ Camm, I Savelieva

TABLE I (continued) Rates of progression of paroxysmal atrial fibrillation to persistent or permanent atrial fibrillation.

\begin{tabular}{|c|c|c|c|c|c|c|}
\hline Study & $\begin{array}{l}\text { Number } \\
\text { of } \\
\text { patients }\end{array}$ & Age, years & Type of AF & $\begin{array}{l}\text { Follow- } \\
\text { up, years }\end{array}$ & $\begin{array}{l}\text { Progression of } \\
\text { AF, \% }\end{array}$ & \begin{tabular}{|l} 
Predictors of \\
progression (risk)
\end{tabular} \\
\hline CARAF, 2005 & 757 & 64 (median) & $\begin{array}{l}\text { First detected } \\
\text { paroxysmal }\end{array}$ & 8 & $\begin{array}{l}8.6 \text { at } I \text { year } \\
24.7 \text { at } 5 \text { years } \\
\text { Any recurrent AF: } \\
63.2 \text { at } 5 \text { years }\end{array}$ & $\begin{array}{l}\text { Age (I.4 per decade), } \\
\text { cardiomyopathy }(2.4 \mathrm{I}) \text {, } \\
\text { aortic stenosis }(3.04) \\
\text { mitral regurgitation } \\
\text { (I.69), LA enlargement } \\
(3.05-4.17)\end{array}$ \\
\hline $\begin{array}{l}\text { Danish Study, } \\
1986\end{array}$ & 426 & 66 (median) & Paroxysmal & $\begin{array}{l}9 \\
\text { (median) }\end{array}$ & 33.1 & $\begin{array}{l}\text { Underlying heart disease, } \\
\text { thromboembolism }\end{array}$ \\
\hline $\begin{array}{l}\text { Kato (Tokyo), } \\
2004\end{array}$ & 171 & $58.3 \pm 11.8$ & $\begin{array}{l}\text { First detected, } \\
\text { paroxysmal }\end{array}$ & 14 & $\begin{array}{l}57 \text { at } 10 \text { years } \\
77 \text { at } 15 \text { years }\end{array}$ & $\begin{array}{l}\text { Age ( } 1.27 \text { per decade), } \\
\text { myocardial infarction } \\
(2.33) \text {, valvular heart } \\
\text { disease ( } 2.29) \text {, LA } \\
\text { enlargement (I.39) } \\
\end{array}$ \\
\hline $\begin{array}{l}\text { Olmsted } \\
\text { County, } 1987\end{array}$ & 88 & 44 & Lone AF & 14.8 & \begin{tabular}{|l} 
Recurrent \\
paroxysmal: 58 \\
Sustained: I 2 \\
\end{tabular} & - \\
\hline $\begin{array}{l}\text { Olmsted } \\
\text { County, } 2007\end{array}$ & 71 & $44.2 \pm 11.7$ & $\begin{array}{l}\text { Lone AF: } \\
48 \% \\
\text { paroxysmal, } \\
52 \% \text { persistent }\end{array}$ & 25.2 & $\begin{array}{l}\text { 3I (30-year } \\
\text { probability: 29) }\end{array}$ & $\begin{array}{l}\text { Age (I.7 per decade), } \\
\text { QRS abnormalities (3.2) }\end{array}$ \\
\hline \multicolumn{7}{|c|}{ 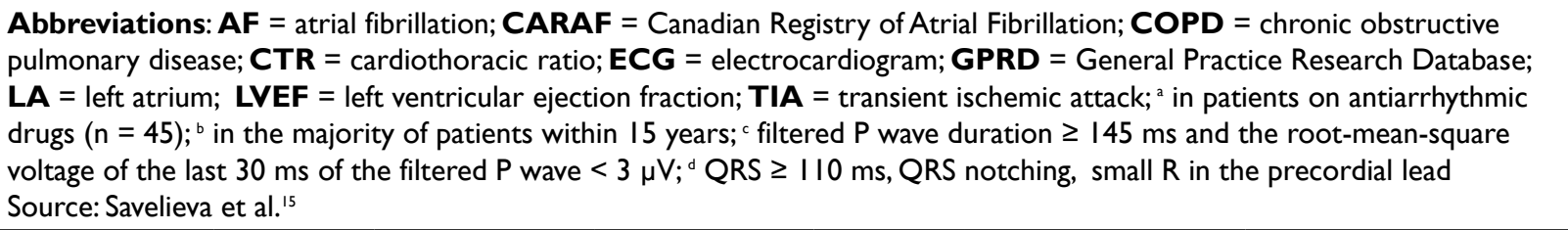 } \\
\hline
\end{tabular}

reduction of quality of life. Therefore there has been equipoise as to whether it is best to accept the arrhythmia while controlling the ventricular rate and preventing thromboembolic complications with anticoagulant therapy, or to restore and maintain sinus rhythm, and of course maintain anticoagulant therapy since it is likely that there will be unpredictable recurrences.

The difficulties in rhythm control management, principally the high AF recurrence rate and concern about the serious adverse effects associated with antiarrhythmic drug therapy, led to rate versus rhythm control studies.

\section{THE RATE VERSUS RHYTHM CONTROL TRIALS}

The Atrial Fibrillation Follow up Investigation of Rhythm Management (AFFIRM) trial, the RAte Control versus Electrical cardioversion (RACE) trial, and most recently the Atrial Fibrillation Congestive Heart Failure (AF CHF) trial are the major studies in this area ${ }^{15,17,18}$ (Table 2). There have also been a series of small or pilot studies, including the Pharmacological Intervention in Atrial Fibrillation (PIAF), Strategies of Treatment of Atrial
Fibrillation (STAF), and How tO Treat Chronic Atrial Fibrillation (HOT CAFÉ) among others. ${ }^{18-20}$

All of these randomised clinical trials directly and prospectively compared the effects of rhythm control treatment strategies with rate control strategies on a variety of endpoints ranging from exercise tolerance to all-cause mortality. Generally, no consistent differences between the strategies have been demonstrated, except for more hospitalizations and the costs associated with rhythm control. However the trials highlighted a trend toward improved survival and less serious cardiovascular adverse events in patients treated with a rate rather than rhythm control strategy.

The AFFIRM study of 4060 AF patients aged 65 years or older, with at least one risk factor for stroke, was the only trial designed to assess, as a primary endpoint, all-cause mortality benefit from these different strategies for AF management. ${ }^{21}$ The mean follow-up was 3.5 years, with a maximum of six years. There was no difference in the primary endpoint of all-cause mortality or quality of life and functional status between rate and rhythm control. 
TABLE 2 Clinical outcomes in rhythm versus rate control studies.

\begin{tabular}{|c|c|c|c|c|c|c|c|c|}
\hline Study & PIAF & STAF & $\begin{array}{l}\text { HOT } \\
\text { CAFE }\end{array}$ & RACE & AFFIRM & AF-CHF & CRRAFT & $\begin{array}{l}\text { J- } \\
\text { RHYTHM }\end{array}$ \\
\hline $\begin{array}{l}\text { Number of } \\
\text { patients }\end{array}$ & 252 & 200 & 205 & 522 & 4060 & 1376 & 144 & 823 \\
\hline $\begin{array}{l}\text { Follow-up, } \\
\text { years }\end{array}$ & 1 & 1.6 & 1.7 & 2.3 & 3.5 & 3.1 & 1 & 1.6 \\
\hline $\begin{array}{l}\text { Primary } \\
\text { endpoint }\end{array}$ & $\begin{array}{l}\text { Symptom } \\
\text { improve- } \\
\text { ment }\end{array}$ & $\begin{array}{l}\text { ACM, CV } \\
\text { events, } \\
\text { CPR, TE }\end{array}$ & $\begin{array}{l}\text { ACM,TE, } \\
\text { bleeding }\end{array}$ & $\begin{array}{l}\text { CV death, } \\
\text { hospitalization } \\
\text { for CHF, } \\
\text { TE, bleeding, } \\
\text { pacemaker, } \\
\text { AAD adverse } \\
\text { effects }\end{array}$ & ACM & $\begin{array}{l}\mathrm{CV} \\
\text { mortality }\end{array}$ & $\begin{array}{l}\text { Clinical } \\
\text { improve- } \\
\text { ment }\end{array}$ & $\begin{array}{l}\text { ACM,TE, } \\
\text { bleeding, } \\
\text { hospital- } \\
\text { ization } \\
\text { for CHF, } \\
\text { adverse } \\
\text { effects }\end{array}$ \\
\hline $\begin{array}{l}\text { Difference } \\
\text { in primary } \\
\text { endpoint } \\
\text { RhyC vs } \\
\text { RC }\end{array}$ & $\begin{array}{l}\text { Symptoms } \\
\text { improved } \\
\text { in } 70 \text { vs } \\
76 \mathrm{pts} \\
(p=0.317)\end{array}$ & $\begin{array}{l}5.54 \% / y r \text { vs } \\
6.09 \% / y r \\
(p=0.99)\end{array}$ & $\begin{array}{l}\text { No } \\
\text { difference } \\
\text { (OR, I.98; } \\
95 \% \mathrm{Cl} \\
0.28-22.3 \\
\mathrm{P}>0.7 \mathrm{I}) \\
\end{array}$ & $\begin{array}{l}22.6 \% \text { vs } \\
\text { I7.2\% (HR, } \\
0.73 ; 90 \% \mathrm{Cl}, \\
0.53-1.01 ; \\
\mathrm{p}=0.1 \mathrm{I})\end{array}$ & \begin{tabular}{|l|}
$23.8 \%$ vs \\
$21.3 \%$ \\
$(\mathrm{HR}, \mathrm{I.I} 5$ \\
$95 \% \mathrm{Cl}$ \\
$0.99-1.34$ \\
$\mathrm{P}=0.08)$ \\
\end{tabular} & $\begin{array}{l}27 \% \text { vs } \\
25 \% \\
(\mathrm{HR}, \mathrm{I} .06 ; \\
95 \% \mathrm{Cl} \\
0.86-1.3 ; \\
\mathrm{P}=0.59) \\
\end{array}$ & $\begin{array}{l}\text { Significant } \\
\text { improve- } \\
\text { ment with } \\
\text { RhyC }\end{array}$ & $\begin{array}{l}15.3 \% \text { vs } \\
22 \% \\
(p=0.0128)\end{array}$ \\
\hline $\begin{array}{l}\text { ACM RhyC } \\
\text { vs RC }\end{array}$ & $\begin{array}{l}\text { Not } \\
\text { assessed }\end{array}$ & $\begin{array}{l}2.5 \% / y r \text { vs } \\
4.9 \% / y r\end{array}$ & $\begin{array}{l}3(2.9 \%) \text { vs } \\
1(1 \%)\end{array}$ & $6.8 \%$ vs $7 \%$ & As above & $\begin{array}{l}32 \% \text { vs } \\
33 \% \\
(p=0.68)\end{array}$ & $\begin{array}{l}0 \text { vs } 5 \\
(p=0.023)\end{array}$ & $\begin{array}{l}4(1 \%) \text { vs } 3 \\
(0.7 \%)\end{array}$ \\
\hline $\begin{array}{l}\text { TE RhyC vs } \\
\text { RC }\end{array}$ & $\begin{array}{l}\text { Not } \\
\text { assessed }\end{array}$ & $\begin{array}{l}3.1 \% / y r \text { vs } \\
0.6 \% / y r\end{array}$ & $\begin{array}{l}3(2.9 \%) \text { vs } \\
1(1 \%)\end{array}$ & $\begin{array}{l}7.9 \% \text { vs } 5.5 \% \\
\text { RhyC vs RC }\end{array}$ & \begin{tabular}{|l|} 
Stroke: \\
$7.1 \%$ vs \\
$5.5 \%$ \\
$(p=0.79)$ \\
\end{tabular} & $\begin{array}{l}3 \% \text { vs } 4 \% \\
(p=0.32)\end{array}$ & I vs 0 & $\begin{array}{l}2.39 \% \text { vs } \\
2.97 \%\end{array}$ \\
\hline $\begin{array}{l}\text { CHF RhyC } \\
\text { vs RC }\end{array}$ & $\begin{array}{l}\text { Not } \\
\text { assessed }\end{array}$ & $\begin{array}{l}\text { Better with } \\
\text { RC }\end{array}$ & $\begin{array}{l}\text { No } \\
\text { difference }\end{array}$ & $4.5 \%$ vs $3.5 \%$ & $\begin{array}{l}2.7 \% \text { vs } \\
2.1 \% \\
(p=0.58)\end{array}$ & $\begin{array}{l}28 \% \text { vs } 31 \% \\
(p=0.17)\end{array}$ & $\begin{array}{l}\text { Functional } \\
\text { class } \\
\text { improved } \\
\text { in } 60 \% \\
\text { vs } 17.5 \% \\
(p=0.00 \mid 4) \\
\end{array}$ & $\begin{array}{l}0.5 \% \text { vs } \\
1.5 \%\end{array}$ \\
\hline $\begin{array}{l}\text { Hospitali- } \\
\text { sation } \\
\text { RhyC vs } \\
\text { RC }\end{array}$ & $\begin{array}{l}69 \% \text { vs } 24 \% \\
(p=0.001)^{a}\end{array}$ & \begin{tabular}{|l|}
$54 \%$ vs \\
$26 \%$ \\
$(p<0.00 I)$
\end{tabular} & $\begin{array}{l}74 \% \text { vs } \\
I 2 \% \\
(p<0.00 I)\end{array}$ & More in RhyC & \begin{tabular}{|l|}
$80 \%$ vs \\
$73 \%$ \\
$(p<0.001)^{a}$
\end{tabular} & $\begin{array}{l}46 \% \text { vs } 39 \% \\
(p=0.0063)\end{array}$ & $\begin{array}{l}8.9 \% \\
\text { vs } 15 \% \\
(p=0.51)\end{array}$ & $\begin{array}{l}\text { Not } \\
\text { reported }\end{array}$ \\
\hline $\begin{array}{l}\text { QoL RhyC } \\
\text { vs RC }\end{array}$ & $\begin{array}{l}\text { No } \\
\text { difference }\end{array}$ & $\begin{array}{l}\text { No } \\
\text { difference }\end{array}$ & $\begin{array}{l}\text { Not } \\
\text { reported }\end{array}$ & No difference & $\begin{array}{l}\text { No } \\
\text { difference }\end{array}$ & $\begin{array}{l}\text { Not yet } \\
\text { available }\end{array}$ & $\begin{array}{l}\text { Improved } \\
\text { in } 86.7 \% \\
\text { vs } 50 \% \\
(p=0.033)\end{array}$ & $\begin{array}{l}\text { Better with } \\
\text { RhyC }\end{array}$ \\
\hline \multicolumn{9}{|c|}{ 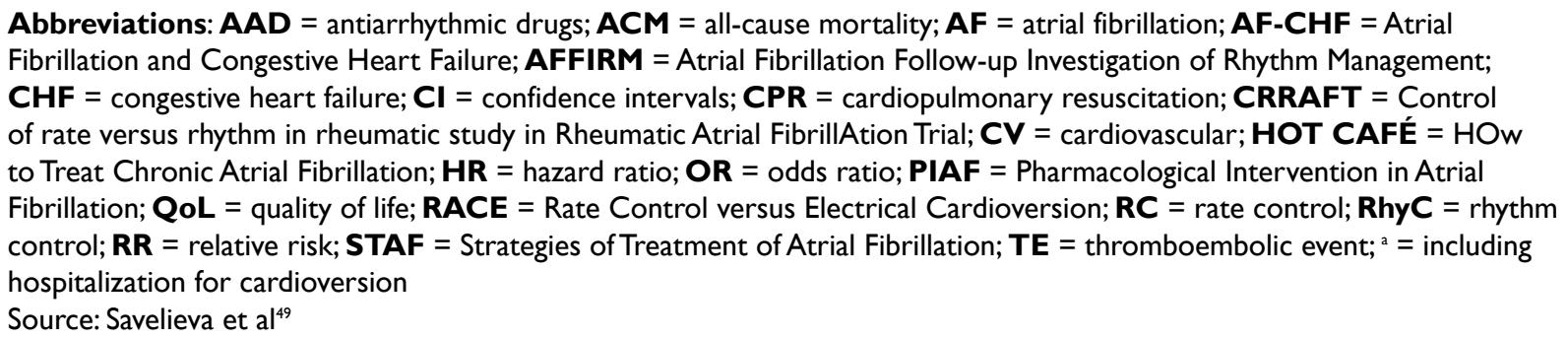 } \\
\hline
\end{tabular}

However, this and other trials did not include younger, active or highly symptomatic patients, initial rate control could not have been easily applied to their management.

Post hoc analysis of the AFFIRM trial, after correction for any mismatch of baseline characteristics, has demonstrated that being in sinus rhythm was an advantage, but that the use of the then available antiarrhythmic drugs was associated with an increased risk of death. ${ }^{22}$

In the AF-CHF trial, rate and rhythm control strategies were compared specifically in 1376 patients with an ejection fraction of $35 \%$ or less and a New York Heart Association (NYHA) classification of II to IV heart 
AJ Camm, I Savelieva

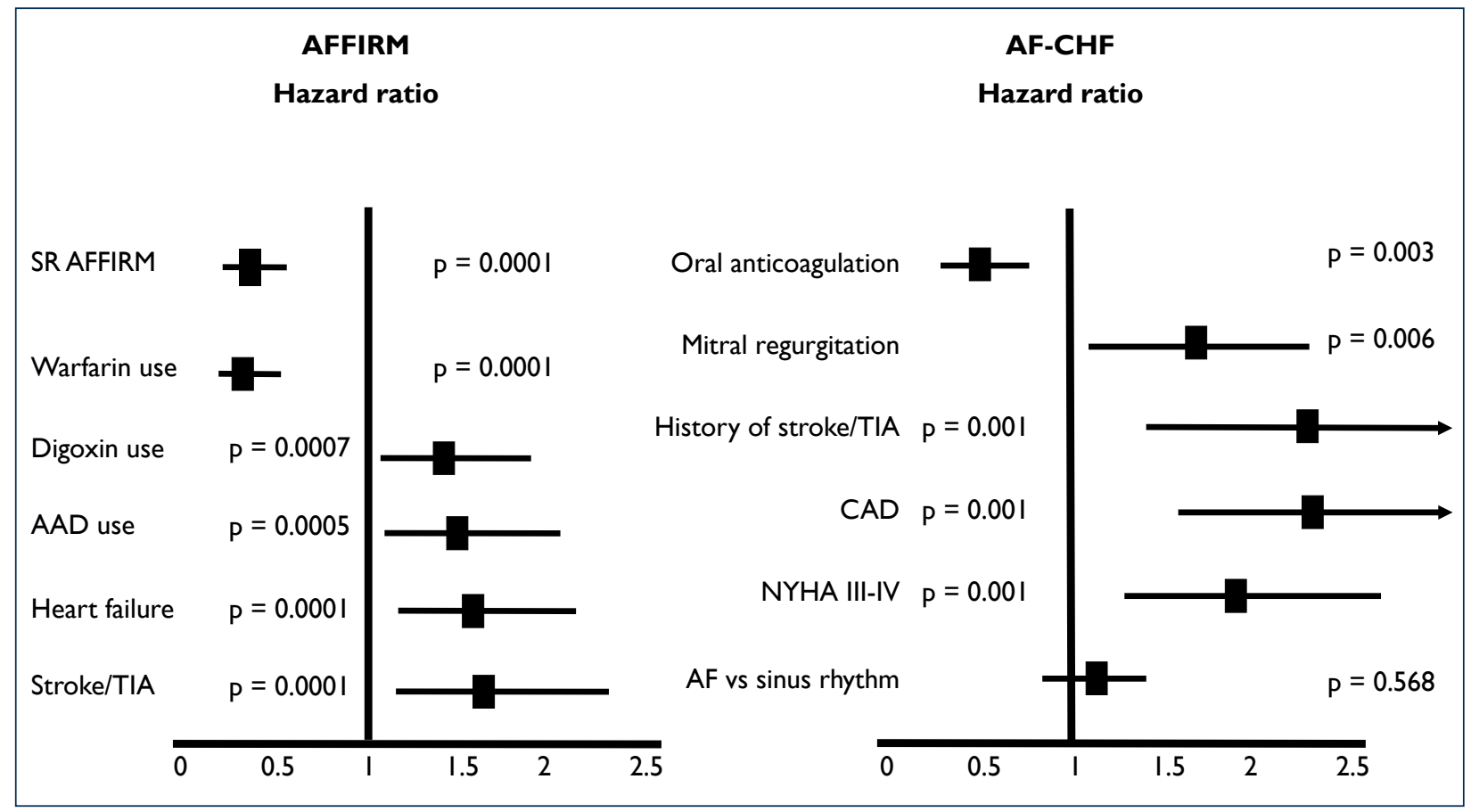

Abbreviations: $\mathbf{A A D}=$ antiarrhythmic drugs; $\mathbf{A F}=$ atrial fibrillation; $\mathbf{C A D}=$ coronary artery disease $\mathbf{N Y H A}=\mathbf{N e w}$ York Heart Association; $\mathbf{S R}=$ sinus rhythm; TIA = transient ischemic attack

\section{FIGURE I Sub group analyses of AFFIRM and RACE illustrating discrepant results with regard to the} presence of sinus rhythm

failure..$^{23}$ Amiodarone was the drug of choice (used in $82 \%$ of cases) for AF suppression and sinus rhythm maintenance, but sotalol and dofetilide were also used in select cases. The study showed no benefit to using rhythm control in addition to optimal medical therapy with regard to the primary endpoint (cardiovascular mortality) and pre-specified secondary endpoints (including total mortality, worsening heart failure, stroke, and hospitalization). Rhythm management was also found to be more expensive than rate control. Unlike the AFFIRM trial, the results of the AF-CHF trial did not confirm an advantage to using sinus rhythm in treating a population of elderly patients with heart failure (Figure I). ${ }^{24}$

The similar primary endpoint results from using the rhythm and rate control strategies may have been due to a general failure to achieve a clear difference with respect to rhythm and rate status in the two arms of the trials. Ideally the rhythm control arm should have included patients who were in sinus rhythm, whereas the rate control arm should have consisted mostly of patients in AF. This was not however typically the case; in the AFFIRM trial for example, only $60 \%$ of the rhythm control arm were maintained in sinus rhythm, while $40 \%$ of the rate control arm had reverted spontaneously to sinus rhythm.

The generally neutral results of the rate versus rhythm control trials were broadly accepted by the clinical community. They were interpreted to imply that rate control therapy should be the primary therapeutic option for patients with recurrent forms of $\mathrm{AF}^{25}$ The reasons for this are not entirely clear but mostly relate to a belief that rate control is logistically easier than rhythm control, to the well-documented reduction in hospitalizations associated with rate control, and to the trend towards better major cardiovascular outcomes in favour of rate control (seen particularly in the AFFIRM and RACE trials). There was therefore a major shift towards the use of rate control and this was reinforced by the guidelines from the ACC, AHA and ESC published in 200I and 2006..$^{26,27}$ The advice from the 2006 guideline regarding rate versus rhythm control for patients with paroxysmal AF is summarised in Figure 2.

However, these interpretations (i.e. initial treatment with rate control agents and later, and therefore delayed, treatment with rhythm control drugs only if symptoms persisted) were not accepted by the arrhythmia and electrophysiology community who were treating younger, more symptomatic patients. This was primarily because these patients had not been included in the relevant trials, and also because the treatment of recurrent $A F$ was beginning to change dramatically at that time. A new antiarrhythmic agent was about to emerge, paroxysmal AF and some persistent AF were increasingly treated with direct left atrial ablation (such as pulmonary vein isolation) and the idea that interventional treatment would be much more successful and might even be 'curative' if adopted early in the course of the disease was spreading. ${ }^{28}$ 


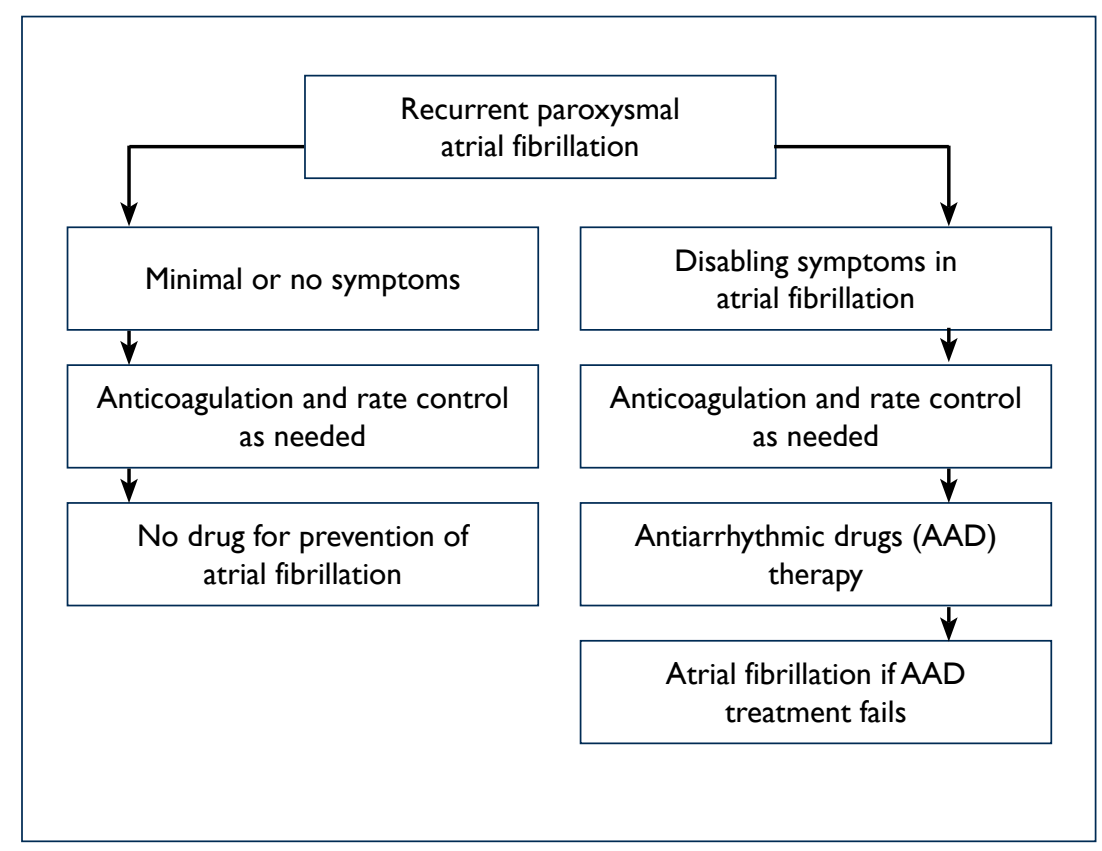

TABLE 3 Randomised controlled studies of pulmonary vein ablation versus antiarrhythmic drug therapy in atrial fibrillation.

\begin{tabular}{|c|c|c|c|c|c|c|}
\hline \multirow[t]{2}{*}{ Study } & \multirow{2}{*}{$\begin{array}{l}\text { Number of } \\
\text { patients }\end{array}$} & \multirow[t]{2}{*}{ Type of AF } & \multirow{2}{*}{$\begin{array}{l}\text { Previous use } \\
\text { of AAD }\end{array}$} & \multirow{2}{*}{$\begin{array}{l}\text { Crossed to } \\
\text { ablation in } \\
\text { the ADD } \\
\text { Group }\end{array}$} & \multicolumn{2}{|c|}{ AF free at one year } \\
\hline & & & & & Ablation & AAD \\
\hline $\begin{array}{l}\text { Krittayaphong } \\
\text { et al, } 2003\end{array}$ & 30 & $\begin{array}{l}\text { Paroxysmal, } \\
\text { persistent }\end{array}$ & $\geq 1$ & Not stated & $79 \%$ & $40 \%$ \\
\hline $\begin{array}{l}\text { Wazni et al, } \\
2005 \text { (RAAFT) }\end{array}$ & 70 & Mainly paroxysmal & No & $49 \%^{a}$ & $87 \%$ & $37 \%$ \\
\hline $\begin{array}{l}\text { Stabile et al, } \\
2005 \text { (CACAF) }\end{array}$ & 137 & $\begin{array}{l}\text { Paroxysmal, } \\
\text { persistent }\end{array}$ & $\geq 2$ & $57 \%$ & $56 \%$ & $9 \%$ \\
\hline Oral et al, 2006 & 146 & Persistent & $\begin{array}{l}\geq \mathrm{I} \\
\text { (mean } 2.1 \pm \\
\mathrm{I} .2 \text { ) }\end{array}$ & $77 \%$ & $74 \%$ & $4 \%$ \\
\hline $\begin{array}{l}\text { Pappone et al, } \\
2006 \text { (APAF) }\end{array}$ & 198 & Paroxysmal & $\begin{array}{l}\geq 2 \\
(\text { mean } 2 \pm \mathrm{I})\end{array}$ & $42 \%$ & $86 \%$ & $22 \%$ \\
\hline $\begin{array}{l}\text { Jais et al, } 2008 \\
\text { (A4 study) }\end{array}$ & 112 & Paroxysmal & $\geq 1$ & $63 \%$ & $89 \%$ & $23 \%$ \\
\hline $\begin{array}{l}\text { Forleo et al, } \\
2008\end{array}$ & 70 & $\begin{array}{l}\text { Paroxysmal, } \\
\text { persistent }\end{array}$ & $\geq 1$ & Not stated & $80 \%$ & $43 \%$ \\
\hline $\begin{array}{l}\text { Wilber } \\
\text { et al, } 2009 \\
\text { (Thermocool) }\end{array}$ & 167 & Paroxysmal & $\begin{array}{l}\geq 1 \\
\text { (mean I.3) }\end{array}$ & $59 \%^{a}$ & $66 \%$ & $16 \%$ \\
\hline $\begin{array}{l}\text { Packer et al, } \\
2010 \text { (STOP- } \\
\text { AF) }\end{array}$ & 245 & Paroxysmal & $\geq 1$ & $79 \%$ & $69.9 \%$ & $7.3 \%$ \\
\hline \multicolumn{7}{|c|}{$\begin{array}{l}\text { Abbreviations: AAD = antiarrhythmic drugs; } \mathbf{A F}=\text { atrial fibrillation; } \mathbf{A P A F}=\text { Ablation for Paroxysmal Atrial Fibrillation } \\
\text { study; } \mathbf{A} 4=\text { Atrial fibrillation Ablation versus AntiArrhythmic drugs; } \mathbf{C A C A F}=\text { Catheter Ablation for the Cure of Atrial } \\
\text { Fibrillation study; } \mathbf{R A A F T}=\text { Radiofrequency Ablation Atrial Fibrillation Trial; STOP-AF = Sustained Treatment of Paroxysmal } \\
\text { Atrial Fibrillation; }{ }^{2}=\text { after I year } \\
\text { Source: Camm AJ et al. } .^{50}\end{array}$} \\
\hline
\end{tabular}


AJ Camm, I Savelieva

TABLE 4 Long-term results of pulmonary vein ablation for atrial fibrillation

\begin{tabular}{|c|c|c|c|c|c|c|}
\hline Study & Study type & $\begin{array}{l}\text { Number } \\
\text { of patients }\end{array}$ & $\begin{array}{l}\text { Ablation } \\
\text { strategy }\end{array}$ & $\begin{array}{l}\text { Follow-up, } \\
\text { months } \\
( \pm S D)\end{array}$ & $\begin{array}{l}\text { Arrhythmia } \\
\text { free survival, } \\
\%\end{array}$ & $\begin{array}{l}\text { Compli- } \\
\text { cations, \% }\end{array}$ \\
\hline Gaita et al, 2008 & $\begin{array}{l}\text { Randomised I:I } \\
\text { PVI vs. PVI + LL }\end{array}$ & 204 & $\mathrm{PVI} / \mathrm{PVI}+\mathrm{LL}$ & $\begin{array}{l}41.4 \pm 6.2 / \\
39.7 \pm 5.5\end{array}$ & 41 & 2 \\
\hline Fiala et al,2008 & $\begin{array}{l}\text { Randomised I:I } \\
\text { segmental PVI vs } \\
\text { circumferential PVI }\end{array}$ & 110 & PVI & $48 \pm 8$ & 56 & 1 \\
\hline $\begin{array}{l}\text { Bertaglia et al, } \\
2009\end{array}$ & Observational & 177 & $\mathrm{PVI} / \mathrm{PVI}+\mathrm{LL}$ & $49.7 \pm 13.3$ & 58 & Not reported \\
\hline $\begin{array}{l}\text { Bhargava et al, } \\
2009\end{array}$ & Observational & 1404 & $\mathrm{PVI} / \mathrm{PVI}+\mathrm{LL}$ & $59 \pm 16$ & 73 & 3 \\
\hline Tsou et al, 2010* & Observational & 123 & PVI & $71 \pm 18$ & 71 & Not reported \\
\hline Wokhlu et al, 2010 & Observational & 774 & $\mathrm{PVI} / \mathrm{PVI}+\mathrm{LL}$ & $36 \pm 22.8$ & 64 & Not reported \\
\hline Ouyang et al, 2010 & Observational & 161 & PVI & 57.6 & 47 & 2 \\
\hline $\begin{array}{l}\text { Weerasooriya } \\
\text { et al, 201 I }\end{array}$ & Observational & 100 & $\mathrm{PVI} / \mathrm{PVI}+\mathrm{LL}$ & 60 & 32 & 6 \\
\hline \multicolumn{7}{|c|}{$\begin{array}{l}\text { Abbreviations: } \mathbf{L L}=\text { left lines; } \mathbf{P V I}=\text { pulmonary vein isolation; } \mathbf{S D}=\text { standard deviation } \\
\text { *only patients free from } \mathrm{AF} \text { one year after ablation were included; in a total of } 239 \text { patients who underwent } A F \text { ablation, the } \\
\text { success rate after } 7 \mathrm{II} \pm 18 \text { months was only } 36.4 \%\end{array}$} \\
\hline
\end{tabular}

\section{CURRENT STATUS OF RATE VERSUS RHYTHM STRATEGIES}

The results of rate versus rhythm control studies highlighted the limitations of the therapies at that time to achieve and maintain sinus rhythm. Long-term maintenance of sinus rhythm has proven difficult to achieve in patients with persistent $\mathrm{AF}$, and the strategy is time-consuming and expensive due to the costs of the antiarrhythmic drugs and the increased need for hospitalization. Little was known about the criteria for adequate and safe rate control. ${ }^{29} \mathrm{~A}$ study from the AFFIRM database, and another comparing the results of AFFIRM (strict rate control) to RACE (lenient rate control) suggested that a lenient approach to rate control is at least as effective as a strict rate control procedure. ${ }^{30}$ This conclusion was confirmed by a recent prospective randomised trial comparing strict control $(<80$ beats/minute at rest and $<110$ beats/minute on moderate exercise) with lenient control ( $<110$ beats/ minute at rest). ${ }^{31}$ Strict rate control was associated with more bradycardia and pacemaker implantation. These developments imply that the therapeutic emphasis on rate control may be tempered or even reversed if safer and more effective rhythm control therapies were to become available.

The use of left atrial ablation to isolate triggers, most often by pulmonary vein isolation, and/or to break up the substrate for AF by creating lines of block or eradicating areas of critical slow conduction, have proved successful in reducing the recurrence of $\mathrm{AF}$
(Table 3). ${ }^{32,33}$ This is particularly true in patients with paroxysmal AF of short duration, normal left atrial anatomy and size, and normal left ventricular function. The results with persistent $A F$, or with $A F$ which would otherwise be designated as permanent, are also encouragingly positive, even when significant left ventricular systolic dysfunction is present. ${ }^{34}$ Often more than one procedure is needed, particularly in the complex cases mentioned above. ${ }^{35}$ There is also some concern about long-term recurrence which is now recognised to be about $5 \%$ per annum even in patients who remain arrhythmia-free for the first year or so. $^{36-38}$ The recurrences tend to be short in duration however and relatively infrequent. Further ablation procedures may be needed and are often successful (Table 4).

Dronedarone is a new antiarrhythmic drug, structurally similar to amiodarone, but it does not contain iodine and is not lipophilic. ${ }^{39}$ Significant cutaneous or thyroid effects have not been seen. The electrophysiological spectrum of the drug also differs significantly from that of amiodarone - it is a more powerful sodium, calcium and acetylcholine-dependent $\mathrm{K}$ current (IKACh) blocker. This drug is an effective antiarrhythmic agent, also shown to reduce hospitalizations for $\mathrm{AF}$ and $\mathrm{AF}$ related co-morbidities, such as heart failure, and acute coronary syndrome in patients with recurrent forms of AF (Table 5). ${ }^{40,41}$ Dronedarone, however, appears not to be safe to use in patients with severe heart failure ${ }^{42}$ or permanent $\mathrm{AF}$, especially in the presence of heart failure. ${ }^{43}$ There is some concern over severe liver toxicity, ${ }^{44}$ which has been 
TABLE 5 Summary of clinical studies of dronedarone in atrial fibrillation.

\begin{tabular}{|c|c|c|c|c|c|c|c|}
\hline Study & $\begin{array}{l}\text { Number } \\
\text { of } \\
\text { patients }\end{array}$ & $\begin{array}{l}\text { Patient } \\
\text { character- } \\
\text { istics }\end{array}$ & $\begin{array}{l}\text { Dose of } \\
\text { drone- } \\
\text { darone }\end{array}$ & $\begin{array}{l}\text { Placebo } \\
\text { cont- } \\
\text { rolled }\end{array}$ & $\begin{array}{l}\text { Primary } \\
\text { endpoint }\end{array}$ & \begin{tabular}{|l|} 
Follow- \\
up, \\
months
\end{tabular} & $\begin{array}{l}\text { Outcome of drone- } \\
\text { darone vs placebo for } \\
\text { amio-darone }\end{array}$ \\
\hline DAFNE & 199 & $\begin{array}{l}\text { Persistent AF } \\
\text { post } \\
\text { cardioversion }\end{array}$ & $\begin{array}{l}400 \mathrm{mg} \text { bid } \\
600 \mathrm{mg} \text { bid } \\
800 \mathrm{mg} \text { bid }\end{array}$ & Yes & $\begin{array}{l}\text { Time to first AF } \\
\text { recurrence }\end{array}$ & 6 & $\begin{array}{l}\text { Median time to first AF } \\
\text { recurrence on } 400 \text { mg bid: } \\
60 \text { vs } 5.3 \text { days (relative risk } \\
\text { reduction, } 55 \% ; 95 \% \mathrm{Cl} \text {, } \\
28-72 \% \text { p }=0.00 \mathrm{I} \text { ) } \\
\text { The effect was less apparent } \\
\text { at higher doses } \\
\text { Treatment discontinuation } \\
\text { due to adverse effects: } 3.9 \% \text {, } \\
7.6 \%, 22.6 \% \text { on } 400,600 \text {, } \\
800 \text { bid. vs } 0 \%\end{array}$ \\
\hline EURIDIS & 615 & $\begin{array}{l}\text { Paroxysmal } \\
\text { and persistent } \\
\text { AF post } \\
\text { cardioversion }\end{array}$ & $400 \mathrm{mg}$ bid & Yes & $\begin{array}{l}\text { Time to first } A F \\
\text { recurrence }\end{array}$ & 12 & $\begin{array}{l}\text { Median time to first } A F \\
\text { recurrence: } 96 \text { vs } 4 \mathrm{I} \text { days, } \\
P=0.01\end{array}$ \\
\hline ADONIS & 630 & $\begin{array}{l}\text { Paroxysmal } \\
\text { and persistent } \\
\text { AF post } \\
\text { cardioversion }\end{array}$ & $400 \mathrm{mg}$ bid & Yes & $\begin{array}{l}\text { Time to first AF } \\
\text { recurrence }\end{array}$ & 12 & $\begin{array}{l}\text { Median time to first } A F \\
\text { recurrence: } 158 \text { vs } 59 \text { days, } \\
P=0.002\end{array}$ \\
\hline $\begin{array}{l}\text { EURIDIS } \\
\text { and } \\
\text { ADONIS } \\
\text { combined }\end{array}$ & 1237 & $\begin{array}{l}\text { Paroxysmal } \\
\text { and persistent } \\
\text { AF post } \\
\text { cardioversion }\end{array}$ & $400 \mathrm{mg}$ bid & Yes & $\begin{array}{l}\text { Time to first } \mathrm{AF} \\
\text { recurrence }\end{array}$ & 12 & $\begin{array}{l}\text { Median time to first } A F \\
\text { recurrence: I I } 6 \text { vs } 53 \text { days } \\
\text { Recurrence at I } 2 \text { months: } \\
64.1 \% \text { vs } 75.2 \%(\mathrm{HR}, 0.75 \\
95 \% \mathrm{Cl}, 0.65-0.87 ; \mathrm{P}<0.00 \text { I }\end{array}$ \\
\hline $\begin{array}{l}\text { EURIDIS } \\
\text { and } \\
\text { ADONIS } \\
\text { post-hoc }\end{array}$ & 1237 & $\begin{array}{l}\text { Paroxysmal } \\
\text { and persistent } \\
\text { AF post } \\
\text { cardioversion }\end{array}$ & $400 \mathrm{mg}$ bid & Yes & $\begin{array}{l}\text { All-cause } \\
\text { mortality and } \\
\text { hospitalization }\end{array}$ & 12 & $\begin{array}{l}\text { All-cause mortality and } \\
\text { hospitalizations: } 22.8 \% \text { vs } \\
30.9 \%(\mathrm{HR}, 0.73 ; 95 \% \mathrm{Cl} \text {, } \\
0.57-0.93 ; \mathrm{p}=0.01)\end{array}$ \\
\hline ERATO & 630 & $\begin{array}{l}\text { Permanent } \\
\text { AF with } \\
\text { ventricular } \\
\text { rates }>80 \\
\text { bpm on rate } \\
\text { controlling } \\
\text { therapy }\end{array}$ & $400 \mathrm{mg}$ bid & Yes & $\begin{array}{l}\text { Mean } 24 \text {-hour } \\
\text { ventricular rate } \\
\text { at } 2 \text { weeks }\end{array}$ & 1 & $\begin{array}{l}\text { Il.7 bpm lower on } \\
\text { dronedarone }(p<0.000 \mathrm{I}) \\
24.5 \mathrm{bpm} \text { lower on } \\
\text { dronedarone during } \\
\text { maximal exercise } \\
(\mathrm{p}<0.000 \mathrm{I})\end{array}$ \\
\hline $\begin{array}{l}\text { ANDRO- } \\
\text { MEDA }\end{array}$ & 617 & $\begin{array}{l}\text { Congestive } \\
\text { heart failure; } \\
\text { EF }<0.35\end{array}$ & $400 \mathrm{mg}$ bid & Yes & $\begin{array}{l}\text { All-cause } \\
\text { mortality and } \\
\text { hospitalization } \\
\text { for heart failure }\end{array}$ & $\begin{array}{l}2 \\
\text { (median) }\end{array}$ & $\begin{array}{l}\text { Stopped early because of } \\
\text { excess mortality in the } \\
\text { dronedarone arm: } 8.1 \% \\
\text { vs } 3.8 \%(\mathrm{HR}, 2,13 ; 95 \% \mathrm{Cl} \text {, } \\
\mathrm{I} .07-4.25 ; \mathrm{p}=0.03) \\
\text { Primary endpoint: } 17.1 \% \text { vs } \\
\text { I2.6\% (HR, I.38; } 95 \% \mathrm{Cl} \text {, } \\
0.92-2.09 ; \mathrm{p}=0.12)\end{array}$ \\
\hline ATHENA & 4628 & $\begin{array}{l}\text { Paroxysmal } \\
\text { or persistent } \\
\text { AF with risk } \\
\text { factors }\end{array}$ & $400 \mathrm{mg}$ bid & Yes & $\begin{array}{l}\text { All-cause } \\
\text { mortality and } \\
\text { hospitalization } \\
\text { for cardio- } \\
\text { vascular events }\end{array}$ & $\begin{array}{l}\mathrm{I} .7 \\
\text { (range, } \\
\mathrm{I}-2.5)\end{array}$ & $\begin{array}{l}\text { Primary endpoint: } 31.9 \% \text { vs } \\
\text { 39.4\% (HR, } 0.76 ; 95 \% \mathrm{Cl} \text {, } \\
0.69-0.84 ; \mathrm{p}<0.00 \mathrm{I}) \\
\text { Hospitalization: } 29.3 \% \text { vs } \\
36.9 \% \text { (HR, } 0.74 ; 95 \% \mathrm{Cl}, \\
0.67-0.82 ; \mathrm{p}<0.00 \mathrm{I}) \\
\text { All-cause mortality: } 5 \% \text { vs } \\
6 \%(\mathrm{HR}, 0.84 ; 95 \% \mathrm{cl}, 0.66- \\
\mathrm{I} .08 ; \mathrm{p}=0.18)\end{array}$ \\
\hline
\end{tabular}


AJ Camm, I Savelieva

\begin{tabular}{|c|c|c|c|c|c|c|c|}
\hline Study & $\begin{array}{l}\text { Number } \\
\text { of } \\
\text { patients }\end{array}$ & $\begin{array}{l}\text { Patient } \\
\text { character- } \\
\text { istics }\end{array}$ & $\begin{array}{l}\text { Dose of } \\
\text { drone- } \\
\text { darone }\end{array}$ & $\begin{array}{l}\text { Placebo } \\
\text { cont- } \\
\text { rolled }\end{array}$ & $\begin{array}{l}\text { Primary } \\
\text { endpoint }\end{array}$ & $\begin{array}{l}\text { Follow- } \\
\text { up, } \\
\text { months }\end{array}$ & $\begin{array}{l}\text { Outcome of drone- } \\
\text { darone vs placebo for } \\
\text { amio-darone }\end{array}$ \\
\hline $\begin{array}{l}\text { DION- } \\
\text { YSOS }\end{array}$ & 504 & Persistent AF & $400 \mathrm{mg}$ bid & $\begin{array}{l}\text { No; amio- } \\
\text { darone } \\
\text { used as } \\
\text { an active } \\
\text { comp- } \\
\text { arator }\end{array}$ & $\begin{array}{l}\text { AF recurrence } \\
\text { (including } \\
\text { unsuccessful } \\
\text { direct current } \\
\text { cardioversion } \\
\text { [DCC]) or drug } \\
\text { discontinuation; } \\
\text { secondary safety } \\
\text { endpoints }\end{array}$ & $\begin{array}{l}12 \\
\text { (median, } \\
7)\end{array}$ & $\begin{array}{l}\text { Primary endpoint: } 75.1 \% \\
\text { vs } 58.8 \%(\mathrm{HR}, \mathrm{I} .59 ; 95 \% \mathrm{Cl} \\
\mathrm{I} .28-\mathrm{I} .98 ; \mathrm{p}<0.000 \mathrm{I}) \\
\text { AF recurrence: } \\
36.5 \% \text { vs } 24.3 \% \\
\text { Main safety endpoint: } 39.3 \% \\
\text { vs } 44.5 \%(\mathrm{HR}, 0.80 ; 95 \% \mathrm{Cl} \text {, } \\
0.60-\mathrm{I} .07 ; \mathrm{p}=0.129)\end{array}$ \\
\hline PALLAS & 3149 & $\begin{array}{l}\text { Permanent } \\
\text { AF with risk } \\
\text { factors }\end{array}$ & $400 \mathrm{mg}$ bid & Yes & $\begin{array}{l}\text { MACE } \\
\text { (cardiovascular } \\
\text { death, } \\
\text { myocardial } \\
\text { infarction, } \\
\text { stroke, systemic } \\
\text { embolism) } \\
\text { or unplanned } \\
\text { cardiovascular } \\
\text { hospitalization } \\
\text { and all-cause } \\
\text { mortality }\end{array}$ & $\begin{array}{l}12 \\
\text { (median, } \\
7)\end{array}$ & $\begin{array}{l}\text { Stopped early because } \\
\text { of excess co-primary } \\
\text { endpoints in the } \\
\text { dronedarone arm. } \\
\text { Major adverse cardiac } \\
\text { events (MACE): } 2 \% \text { vs } 0.9 \% \\
\text { (HR, } 2.3 ; \mathrm{p}=0.009) \\
\text { All-cause mortality and } \\
\text { unplanned hospitalization: } \\
7.5 \% \text { vs } 5.1 \% \text { (HR, I.5; p = } \\
0.006) \\
\text { Death: I\% vs } 0.4 \% \text { (HR, 2.3; } \\
\text { P }=0.065)\end{array}$ \\
\hline
\end{tabular}

Abbreviations: ADONIS = American-Australian-African trial with DronedarONe In atrial fibrillation or flutter for the maintenance of Sinus rhythm; AF = atrial fibrillation; ANDROMEDA = ANtiarrhythmic trial with DROnedarone in Moderate to severe heart failure Evaluating morbidity DecreAse; ATHENA = A placebo-controlled, double-blind, parallel arm Trial to assess the efficacy of dronedarone $400 \mathrm{mg}$ bid for the prevention of cardiovascular Hospitalization or death from any cause in patiENts with Atrial fibrillation/atrial flutter; bpm = beats per minute; DAFNE = Dronedarone Atrial FibrillatioN study after Electrical cardioversion; DIONYSOS = Double blind trlal to evaluate efficacy and safety of drOnedarone (400 $\mathrm{mg}$ bid) versus amiodaroNe (600 mg qd for $28 \mathrm{daYs}, 200 \mathrm{mg}$ qd thereafter) for at least six mOnths for the maintenance of Sinus rhythm in patients with atrial fibrillation; EF = ejection fraction; ERATO = Efficacy and Safety of Dronedarone for the Control of Ventricular Rate; EURIDIS = EURopean trial In atrial fibrillation or flutter patients receiving Dronedarone for the maintenance of Sinus rhythm; PALLAS = Permanent Atrial fibriLLation outcome Study

documented in rare cases but detailed post-approval studies have so far failed to confirm the concern. Unlike other drugs, dronedarone has not been associated with any pro-arrhythmia other than mild bradycardia.

Both dronedarone and left atrial ablation are recommended in recent guidelines for the management of patients with recurrent AF. The focused update incorporated into the ACC, AHA and HRS guidelines $(20 \mathrm{I} \mathrm{I})^{45}$ give a class I level recommendation for ablation of paroxysmal AF in optimal circumstances, and the ESC guidelines $(2010)^{13}$ give a class $2 \mathrm{a}$ level recommendation for ablation of both paroxysmal and persistent AF and a $2 b$ level recommendation for ablation of paroxysmal AF without the need to demonstrate failure with previous antiarrhythmic drug therapy. This guideline also supports (class 2b) ablation of AF in patients with systolic heart failure. Both guidelines recommend the use of dronedarone within its licensed indications. The ESC guideline no longer recommends that there should always be an attempt to control symptoms with rate control before considering the adoption of a rhythm control strategy.
Early rhythm control may be important if the strategy is to stand any chance of long-term success.

New 'rate versus rhythm control' trials are urgently needed because younger, more active and more symptomatic patients should be studied. Better therapies than the older antiarrhythmic drugs used in the previous rate versus rhythm trials are now available. Left atrial ablation, and/or possibly dronedarone, might be used to provide safer and more effective rhythm control.

It is suggested that rhythm control should be timed much earlier during the course of the disease in order to prevent the progression of $\mathrm{AF}^{46}$ Left atrial ablation or antiarrhythmic agents might be used to isolate or suppress triggers of AF or modify the substrate for example. If given early in the course of the disease, before substantial atrial remodelling has taken place due to the AF itself ('AF begets AF') or due to the haemodynamic stress associated with underlying diseases such as hypertension and heart failure (which themselves can be aggressively managed), the recurrence of AF may be averted. ${ }^{47}$ Such considerations are the basis 
for large trials such as EAST (Early Atrial fibrillation Stroke Prevention Trial, NCT0 1288352) and CABANA (Catheter ABlation versus ANtiarrhythmic drug therapy for Atrial fibrillation, NCT009I I 508). ${ }^{48}$

\section{CONCLUSIONS}

For the majority of patients with recurrent $A F$ there is abundant and largely consistent randomised clinical trial evidence that the best initial strategy is rate control; rhythm control should only be considered if symptoms remain troublesome. However, little or no such evidence exists in younger, active and highly symptomatic patients.

\section{REFERENCES}

I Savelieva I, Camm J. Update on atrial fibrillation: part I. Clin Cardiol 2008; 31:55-62. http://dx.doi.org/10.1002/clc.20138

2 Naccarelli GV,Varker $\mathrm{H}$, Lin J et al. Increasing prevalence of atrial fibrillation and flutter in the United States. Am J Cardiol 2009; 104:1534-39. http://dx.doi.org/10.1016/j.amjcard.2009.07.022

3 Wolf PA, Abbot RD, Kannel WB. Atrial fibrillation as an independent risk factor for stroke: the Framingham Study. Stroke 1991; 22:983-8. http://dx.doi.org/ I0. I I6I/0I.STR.22.8.983

4 Elijovich L, Josephson SA, Fung GL et al. Intermittent atrial fibrillation may account for a large proportion of otherwise cryptogenic stroke: a study of 30-day cardiac event monitors. J Stroke Cerebrovasc Dis 2009, 18:185-9. http://dx.doi.org/10.1016/j.jstrokecerebrovasdis.2008.09.005

5 Wang TJ, Larson MG, Levy D et al. Temporal relations of atrial fibrillation and congestive heart failure and their joint influence on mortality: the Framingham Heart Study. Circulation 2003; 107:2920 5. http://dx.doi.org/ I0.I I6I/0I.CIR.0000072767.89944.6E

6 Miyasaka Y, Barnes ME, Gersh BJ et al. Coronary ischemic events after first atrial fibrillation: risk and survival. Am J Med 2007; 120:357-63. http://dx.doi.org//0.1016/j.amjmed.2006.06.042

7 Friberg L, Rosenqvist M. Cardiovascular hospitalization as a surrogate endpoint for mortality in studies of atrial fibrillation: report from the Stockholm Cohort Study of Atrial Fibrillation. Europace 20I I; I 3:62633. http://dx.doi.org/ I0.1093/europace/eur00 I

8 Atwood JE, Myers JN, Tang XC et al. Exercise capacity in atrial fibrillation: a substudy of the Sotalol-Amiodarone Atrial Fibrillation Efficacy Trial (SAFE-T). Am Heart J 2007; I53:566-72. http://dx.doi. org/10.1016/j.ahj.2006.12.020

9 Spertus J, Dorian P, Bubien R et al. Development and validation of the Atrial Fibrillation Effect on QualiTy-of-Life (AFEQT) Questionnaire in patients with atrial fibrillation. Circ Arrhythm Electrophysiol 201 I; 4:I525. http://dx.doi.org/ I 0. I I 6 I/CIRCEP.I I 0.958033

10 Kirchhof P, Lip GY,Van Gelder IC et al. Comprehensive risk reduction in patients with atrial fibrillation: emerging diagnostic and therapeutic options - a report from the 3rd Atrial Fibrillation Competence NETwork/European Heart RhythmAssociation consensus conference. Europace 2012; 14:8-27. http://dx.doi.org/I0.1093/europace/eur24 I

I I Lubitz SA, Ozcan C, Magnani JW et al. Genetics of atrial fibrillation: implications for future research directions and personalized medicine. Circ Arrhythm Electrophysiol 2010; 3:29I-9. http://dx.doi. org/ I0. I I6I/CIRCEP.I I0.94244I

I2 Savelieva I, Camm AJ. Clinical relevance of silent atrial fibrillation: prevalence, prognosis, quality of life, and management. J Interv Card Electrophysio/ 2000;4:369-82. http://dx.doi.org//0.1023/A:100982300I707

I3 Camm AJ, Kirchhof P, Lip GY et al. Guidelines for the management of atrial fibrillation: the Task Force for the Management of Atrial Fibrillation of the European Society of Cardiology (ESC). Europace 2010; I2:1360-420. http://dx.doi.org// 0.1093/europace/euq350

14 DeVos CB, Pisters R, Nieuwlaat $R$ et al. Progression from paroxysmal to persistent atrial fibrillation clinical correlates and prognosis. J Am Coll Cardiol 20 10;55:725-3 I.http://dx.doi.org/I0.10 I6/j.jacc.2009.I I.040
There is good evidence that left atrial ablation is considerably better than conventional antiarrhythmic drug therapy for the prevention of paroxysmal AF recurrences, although no trials have yet investigated whether ablation techniques result in a long-term reduction of major cardiovascular outcomes. Nonetheless, the clinical pendulum of rate versus rhythm control is swinging towards rhythm control. Results from large scale randomised clinical trials are urgently needed to evaluate whether a rhythm control strategy in the modern era can surpass rate control in terms of slowing the progression of $A F$, improving quality of life, and reducing cardiovascular consequences, including mortality.

I5 Savelieva I, Kirchhof P, Danchin N et al. Regulatory pathways for development of antiarrhythmic drugs for management of atrial fibrillation/flutter. Europace 2011; 13:1063-76. http://dx.doi. org/10.1093/europace/eur18I

16 Chen PS, Chou CC, Ta AY et al. The mechanisms of atrial fibrillation. J Cardiovasc Electrophysiol 2006; 17:S2-7. http://dx.doi. org/I0.III/j.I540-8167.2006.0026.x

17 Roy D, Talajic M, Nattel S et al. Rhythm control versus rate control for atrial fibrillation and heart failure. N Engl J Med 2008; 358:266777. http://dx.doi.org//0.1056/NEJMoa0708789

I8 Hohnloser SH, Kuck KH, Lilienthal J. Rhythm or rate control in atrial fibrillation - pharmacological intervention in atrial fibrillation (PIAF): a randomised trial. Lancet 2000; 356: I 789-94. http://dx.doi. org/I0.1016/S0I40-6736(00)03230-X

19 Carlsson J, Miketic S, Windeler J et al. Randomized trial of ratecontrol versus rhythm-control in persistent atrial fibrillation. The Strategies of Treatment of Atrial Fibrillation Study. J Am Coll Cardiol 2003; 4I:I690-6. http://dx.doi.org/I0.10I6/S0735-1097(03)00332-2

20 Opolski G, Torbicki A, Kosior DA et al. Rate control vs rhythm control in patients with nonvalvular persistent atrial fibrillation: the results of the Polish How To Treat Chronic Atrial Fibrillation (HOT CAFE) Study. Chest 2004; 126;476-86. http://dx.doi. org/10.1378/chest. I26.2.476

2I Wyse DG, Waldo AL, DiMarco JP et al. A comparison of rate control and rhythm control in patients with atrial fibrillation. $N$ Engl J Med 2002; 347: I825-33. http://dx.doi.org/I0.1056/NEJMoa02 I328

22 Corley SD, Epstein AE, DiMarco JP et al. Relationships between sinus rhythm, treatment, and survival in the Atrial Fibrillation Follow-Up Investigation of Rhythm Management (AFFIRM) Study. Circulation 2004; I09:1509-13. http://dx.doi.org/I0.1 I6I/0I.CIR.0000 I21736.16643.I I

23 Van Gelder IC, Hagens VE, Bosker HA et al. A comparison of rate control and rhythm control in patients with recurrent persistent atrial fibrillation. N Engl J Med 2002; 347:1834-40. http://dx.doi. org/10.1056/NEJMoa021375

24 Talajic M, Khairy P, Levesque $S$ et al. Maintenance of sinus rhythm and survival in patients with heart failure and atrial fibrillation. J Am Coll Cardiol 2010;55:I796-1802. http://dx.doi.org/I0.1016/j.jacc.20I0.01.023

25 Snow V,Weiss KB, LeFevre $M$ et al. Management of newly detected atrial fibrillation: a clinical practice guideline from the American Academy of Family Physicians and the American College of Physicians. Ann Intern Med 2003; 139:1009-17.

26 Fuster V, Rydén LE, Asinger RW et al.ACC/AHA/ESC guidelines for the management of patients with atrial fibrillation. $A$ report of the American College of Cardiology/American Heart Association Task Force on Practice Guidelines and the European Society of Cardiology Committee for Practice Guidelines and Policy Conferences (Committee to develop guidelines for the management of patients with atrial fibrillation) developed in collaboration with the North American Society of Pacing and Electrophysiology. Eur Heart J 200 I; 22: I852-1923. http://dx.doi.org/I0. I053/euhj.200I.2983 
AJ Camm, I Savelieva

27 Fuster V, Rydén LE, Cannom DS et al.ACC/AHA/ESC 2006 guidelines for the management of patients with atrial fibrillation: a report of the American College of Cardiology/American Heart Association Task Force on practice guidelines and the European Society of Cardiology Committee for Practice Guidelines (Writing Committee to Revise the 200I guidelines for the management of patients with atrial fibrillation) developed in collaboration with the European Heart Rhythm Association and the Heart Rhythm Society. Europace 2006; 8:65I-745. http://dx.doi.org// 0.1093/europace/eul097

28 Prystowsky EN, Camm J, Lip GY et al. The impact of new and emerging clinical data on treatment strategies for atrial fibrillation. J Cardiovasc Electrophysiol 2010; 21:946-58.

29 Camm AJ, Savelieva I, Lip GY, Guideline Development Group for the NICE clinical guideline for the management of atrial fibrillation. Rate control in the medical management of atrial fibrillation. Heart 2007; 93:35-8. http://dx.doi.org/ I0.1 I36/hrt.2006.099903

30 Van Gelder IC, Wyse DG, Chandler ML et al. Does intensity of rate-control influence outcome in atrial fibrillation? An analysis of pooled data from the RACE and AFFIRM studies. Europace 2006; 8:935-42. http://dx.doi.org//0.1093/europace/eull 06

3I Van Gelder IC, Groenveld HF, Crijns HJ et al. Lenient versus strict rate control in patients with atrial fibrillation. $N$ Engl J Med 2010; 362: | 363-73. http://dx.doi.org/ I0.1056/NEJMoa I00I 337

32 Piccini JP, Lopes RD, Kong MH et al. Pulmonary vein isolation for the maintenance of sinus rhythm in patients with atrial fibrillation: a metaanalysis of randomized, controlled trials. Circ Arrhythm Electrophysio 2009; 2:626-33. http://dx.doi.org/I0.I I6I/CIRCEP.I09.856633

33 Calkins $H$, Reynolds MR, Spector $P$ et al.Treatment of atrial fibrillation with antiarrhythmic drugs or radiofrequency ablation: two systematic literature reviews and meta-analyses. Circ Arrhythm Electrophysiol 2009, 2:349-6I. http://dx.doi.org/I0.I I6I/CIRCEP.108.824789

34 Wilton SB, Fundytus A, Ghali WA et al. Meta-analysis of the effectiveness and safety of catheter ablation of atrial fibrillation in patients with versus without left ventricular systolic dysfunction. Am J Cardiol 2010; 106:|284-91. http://dx.doi.org//0.1016/j. amjcard.2010.06.053

35 Parkash R,Tang AS, Sapp JL et al.Approach to the catheter ablation technique of paroxysmal and persistent atrial fibrillation: a metaanalysis of the randomized controlled trials. J Cardiovasc Electrophysiol 20I I; 22:729-38. http://dx.doi.org/I0. I I I/j. I540-8I67.20 I I.020I0.x

36 Wokhlu A, Hodge DO, Monahan $\mathrm{KH}$ et al. Long-term outcome of atrial fibrillation ablation: impact and predictors of very late recurrence. J Cardiovasc Electrophysiol 2010; 21:1071-8. http://dx. doi.org/I0.1 III/j.I540-8I67.2010.01786.x

37 Ouyang F, Tilz R, Chun J et al. Long-term results of catheter ablation in paroxysmal atrial fibrillation: lessons from a 5-year follow-up. Circulation 20 I0; 122:2368-77. http://dx.doi.org/ I0.1 I6I/ CIRCULATIONAHA.I 10.946806
38 Weerasooriya R, Khairy P, Litalien J et al. Catheter ablation for atrial fibrillation: are results maintained at 5 years of follow-up? J Am Coll Cardiol 201 I; 57:160-6. http://dx.doi.org/10.1016/j.jacc.2010.05.06 I

39 Savelieva I, Camm J. Anti-arrhythmic drug therapy for atrial fibrillation: current anti-arrhythmic drugs, investigational agents, and innovative approaches. Europace 2008; 10:647-65. http://dx. doi.org/I0.1093/europace/eun I 30

40 Singh BN, Connolly SJ, Crijns HJ et al. Dronedarone for maintenance of sinus rhythm in atrial fibrillation or flutter. $N$ Engl J Med 2007; 357:987-99. http://dx.doi.org/ I0.1056/NEJMoa054686

4I Hohnloser SH, Crijns HJ, van Eickels $M$ et al. Effect of dronedarone on cardiovascular events in atrial fibrillation. $N$ Engl J Med 2009; 360:668-78. http://dx.doi.org/10.1056/NEJMoa0803778

42 Kober L, Torp-Pedersen C, McMurray JJ et al. Increased mortality after dronedarone therapy for severe heart failure. $N$ Engl J Med 2008; 358:2678-87. http://dx.doi.org/ I0.1056/NEJMoa0800456

43 Connolly SJ, Camm AJ, Halperin JL et al. Dronedarone in high-risk permanent atrial fibrillation. N Engl J Med 20II; 365:2268-76. http://dx.doi.org/I0.1056/NEJMoa I 109867

44 Joghetaei N, Weirich G, Huber $W$ et al. Acute liver failure associated with dronedarone. Circ Arrhythm Electrophysiol 20II; 4:592-3. http://dx.doi.org/ I0. I I6 I/CIRCEP.I I I.963447

45 Fuster V, Rydén LE, Cannom DS et al. 20II ACCF/AHA/HRS focused updates incorporated into the ACC/AHA/ESC 2006 guidelines for the management of patients with atrial fibrillation: a report of the American College of Cardiology Foundation/American Heart Association Task Force on practice guidelines. Circulation 201 I; | 23:e269-367. http://dx.doi.org/I0.1 I6I/CIR.0b013e3 |82 I4876d

46 Van Gelder IC, Haegeli LM, Brandes A et al. Rationale and current perspective for early rhythm control therapy in atrial fibrillation. Europace 201 I; I3:1517-25. http://dx.doi.org/10.1093/europace/eur 192

47 Savelieva I, Kakouros N, Kourliouros A et al. Upstream therapies for management of atrial fibrillation: review of clinical evidence and implications for European Society of Cardiology guidelines. Part I: primary prevention. Europace 20II; 13:308-28. http://dx.doi. org/10.1093/europace/eur002

48 ClinicalTrials.gov [Internet]. Maryland: US National Institutes of Health; [cited 20I I Nov 29].Available from: http://www.clinicaltrials. gov

49 Savelieva I, Waldo A, Camm AJ. Atrial fibrillation: rhythm and rate control therapies. In: Yusuf S, Cairns JA, Camm AJ et al, editors. Evidence based cardiology. London:Wiley-Blackwell; 2009. pp. 53I-67.

50 Camm AJ, Savelieva I.Atrial Fibrillation:A4 study: proof of concept? Nat Rev Cardiol 2009; 6:332-4. 